\title{
Thermodynamic modelling of carbonate-silicate rocks from the Sakar unit, Sakar-Strandzha zone, SE Bulgaria
}

\section{Термодинамично моделиране на карбонатно-силикатни скали от Сакарската единица, Сакар-Странджанска зона, ЮИ България}

\author{
Tzvetomila Vladinova ${ }^{1}$, Milena Georgieva ${ }^{2}$ \\ Цветомила Владинова ${ }^{1}$, Милена Георгиева ${ }^{2}$ \\ ${ }^{1}$ Geological Institute, Bulgarian Academy of Sciences, Acad.G. Bonchev str., 1113 Sofia; E-mail: tz.vladinova@gmail.com \\ ${ }^{2}$ Sofia University St. Kliment Ohridski, 15 Tsar Osvoboditel Blvd., 1504 Sofia; E-mail: milena@gea.uni-sofia.bg
}

\begin{abstract}
The P-T evolution of carbonate-bearing metasedimentary rocks from the Sakar unit (Sakar-Strandzha Zone, SE Bulgaria) has been obtained using Perple_X modelling and conventional geothermometry. The metamorphic conditions vary from greenschist facies $\left(250-350{ }^{\circ} \mathrm{C} / 2-4 \mathrm{kbar}\right)$ in the Klokotnitsa village area to amphibolite facies $\left(550-650^{\circ} \mathrm{C} / 4.5-6.5 \mathrm{kbar}\right)$ in the Topolovgrad town area, confirming a general increase of the metamorphic grade at east-west direction.
\end{abstract}

Keywords: thermodynamic modelling, Perple_X, mineral chemistry, Sakar unit, SE Bulgaria.

\section{Introduction and geological setting}

The Sakar-Strandzha Zone (SSZ) is an early Alpine orogenic belt, composed of pre-Triassic metamorphic basement overlain by Triassic-Jurassic metasediments. Post-Triassic greenschist to amphibolite facies metamorphism affected both the basement and the cover (Tzankova, Pristavova, 2007; Chavdarova, Machev, 2017). The two units comprising the SSZ, Sakar and Strandzha (Ivanov, 2017), differ both in their tectonic evolution and metamorphic grade. The metamorphic grade increases in the $\mathrm{Sa}-$ kar unit from west to the east (greenschist to amphibolite), whereas in the Strandzha unit it is lower (greenschist). We studied carbonate-silicate rocks (phyllite and calcite-biotite schist) of the Sakar unit (Topolovgrad Group, Sakar Type Triassic, Chatalov, 1990) in order to elucidate the metamorphic evolution and to constrain the peak P-T conditions. Carbonate-bearing rocks are common in the upper part of the Triassic metasedimentary sequence and provoke us to choose these unconventional rocks for geothemobaromentry. The phyllite (TV-24) was collected in the marble quarry near Klokotnitsa village ( $\left.\mathrm{N} 41^{\circ} 58^{\prime} 38.86, \mathrm{E} 25^{\circ} 34^{\prime} 21.12\right)$ and the calcite- biotite schist (TV-48), from the Topolovgrad town area $\left(\mathrm{N} 42^{\circ} 01^{\prime} 43.30, \mathrm{E} 26^{\circ} 29^{\prime} 37.60\right)$. The phyllite is fine-grained, alternates with carbonate-silicate schists, and shows a pronounced deformation and multiple folds. The calcite-biotite schist, with prominent large biotite flakes associates with layers and lenses of metasandstones of variable thickness (2$25 \mathrm{~cm}$ ). The thermodynamic modelling (software package Perple_X 6.6.9, Connoly, 2009), based on relationship between bulk rock composition and equilibrium mineral assemblages, was combined with conventional geothermometry for rock-forming and accessory minerals.

\section{Petrography and mineral chemistry}

The phyllite has a prominent foliation and crenulation cleavage. The major mineral assemblage comprises fine-grained phyllosilicate minerals (muscovite and chlorite), quartz, calcite and accessory ilmenite, rutile and apatite. The small syn-kinematic porphyroblasts of chlorite, calcite, and muscovite are elongated to the foliation (Fig. 1a). Along the crenulation planes phyllosilicates prevail and the proportion of calcite and quartz is lower. Accord- 

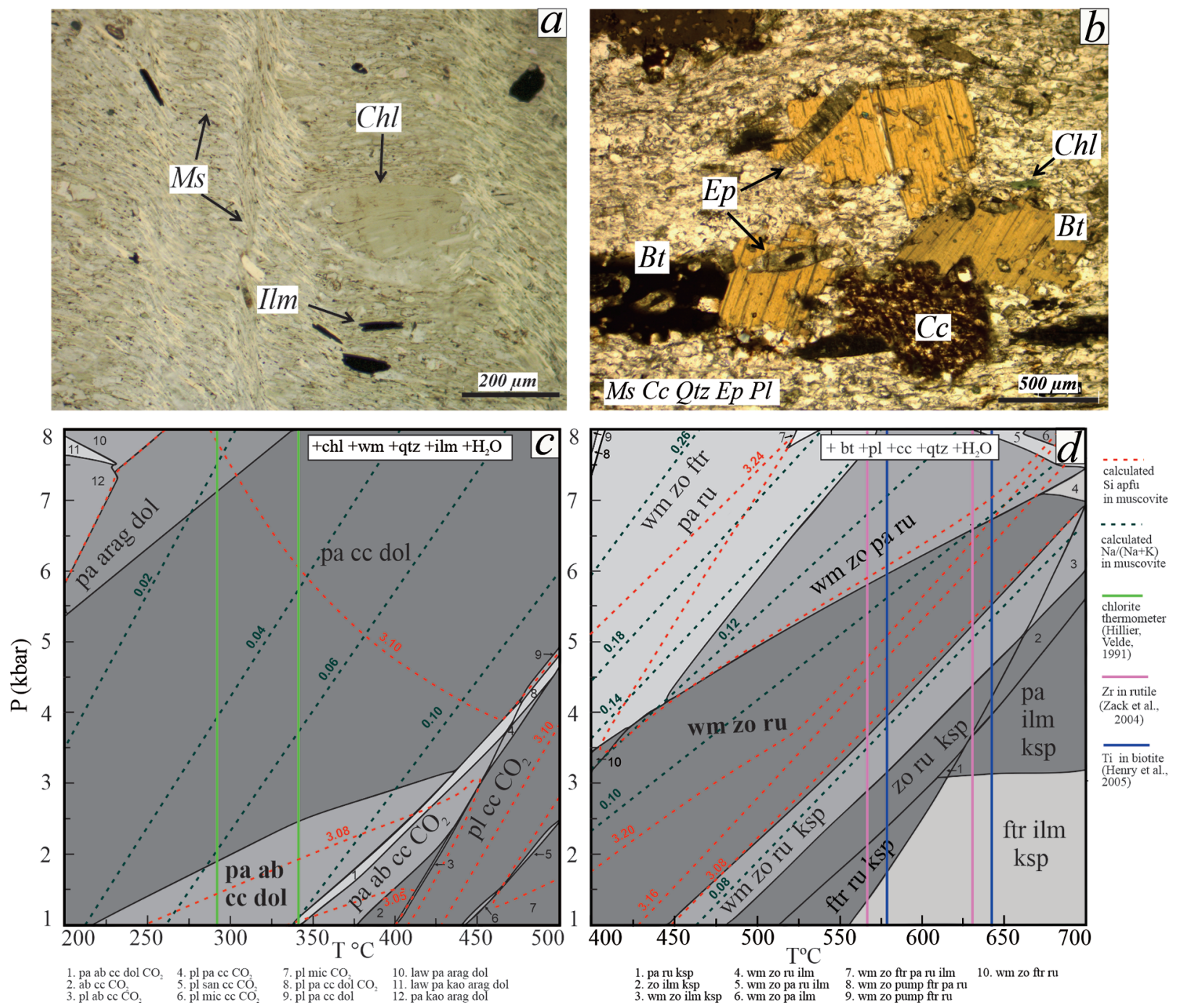

Fig. 1. Photomicrographs in transmitted light $(a, b)$ and Perple_X (6.6.9) models $(c-d)$ calculated with hp04ver.dat thermodynamic data file: $a$, syn-kinematic chlorite porphyroblast in a fine-grained muscovite-rich matrix of phyllite sample TV-24; $b$, syn- to postkinematic biotite porphyroblasts with poikilitic epidote inclusions, surrounded by fine-grained matrix dominated by muscovite and calcite of calcite-biotite schist sample TV-48; $c$, P-T pseudosection of phyllite (TV-24); $d$, P-T pseudosection of calcite-biotite schist (TV-48). Mineral abbreviations: wm, white mica; chl, chlorite; $p a$, paragonite; $b t$, biotite; $q$, quartz; $a b$, albite; $p l$, plagioclase; ksp, K-feldspar; mic, microcline; san, sanidine; cc, calcite; dol, dolomite; arag, aragonite; law, lawsonite; kao, kaolinite; $z o$, zoisite; ftr, ferrotremolite; ilm. ilmenite; ru, rutile.

ing to classification of Hey (1954) the chlorites are ripidolites $(\mathrm{XFe}=0.49-0.52)$. Phengite $(\mathrm{Si}=3.05-$ $3.12 \mathrm{apfu})$ and paragonite $(\mathrm{Na} /(\mathrm{Na}+\mathrm{K})=0.05-0.09)$ content in muscovite show low variation. Albite $\left(\mathrm{An}_{2}\right)$ is present in the matrix and as small inclusions embedded in calcite. Ilmenite is the most abundant accessory mineral. It is sub-hedral, syn- to post-kinematic with small inclusions of rutile.

The calcite-biotite schist is composed of biotite, epidote and calcite porphyroblasts surrounded by fine-grained matrix of muscovite, calcite, epidote, plagioclase, quartz, ilmenite, rutile, and apatite (Fig. 1b). The large euhedral, poikilitic biotite porphyroblasts $(\sim 2 \mathrm{~mm})$ show syn- to post-kinematic growth (Fig. 1b). The chemical zoning of biotite flakes is weak, with $\mathrm{XMg}$ from 0.56 to 0.58 and $\mathrm{TiO}_{2}$ in the range from 1.80 to $2.10 \mathrm{wt} \%$. Numerous inclusions in biotite are from matrix minerals, long prismatic epidote grains, ilmenite and rutile. Most of epidote porphyroblasts have small allanite cores and lower XEp (from 0.64 to 0.75 ), than the smaller grains in the matrix (XEp from 0.71 to 0.79). Muscovite shows rather uniform paragonite $(\mathrm{Na} /(\mathrm{Na}+\mathrm{K})=0.09-0.10)$ and phengite $(\mathrm{Si}=3.13-$ $3.20 \mathrm{apfu}, 11 \mathrm{O}$ atoms) contents. The plagioclase in the matrix is oligoclase $\left(\mathrm{An}_{20-26}\right)$. Large subhedral calcite grains are enveloped by $\mathrm{Fe}$-oxides, that give them a brownish color. The proportion of calcite and 
muscovite in the matrix varies. In calcite-dominated bands the biotite and calcite porphyroblasts are rarer and smaller, reflecting the lack of enough components for biotite, and recrystallization of calcite.

\section{Perple_X modeling}

On P-T pseudosection for phylite bulk composition, the observed stable mineral assemblage (muscovitechlorite-calcite-albite-ilmenite- $\mathrm{H}_{2} \mathrm{O}$ ) appears in a field between 230 and $370{ }^{\circ} \mathrm{C}$ at $1-5$ kbar (Fig. 1c). The calculated compositional isopleths for the $\mathrm{Si}$ content and the $\mathrm{Na} /(\mathrm{Na}+\mathrm{K})$ ratio of the model muscovite correspond to analyzed muscovite composition and cross the selected field. The temperatures derived by the empirical chlorite thermometer of Hillier and Velde (1991) are in the range $280-334^{\circ} \mathrm{C}$, i.e., also fall within the temperature range of the selected stability field. The calculated P-T pseudosection, combined with observed mineral assemblage, compositional isopleths for muscovite and chlorite solid solution geothermometer, correspond to metamorphism in the range $250-350{ }^{\circ} \mathrm{C}$ and $2-4 \mathrm{kbar}$, indicating greenschist facies conditions.

A wide field $\left(400-640{ }^{\circ} \mathrm{C}, 1-6.6 \mathrm{kbar}\right)$ corresponds to the observed mineral association of biotitecalcite-epidote-muscovite-plagioclase-rutile- $\mathrm{H}_{2} \mathrm{O}$ for calcite-biotite schist (Fig. 1d). The analyzed Si (3.13-3.22 apfu, $11 \mathrm{O}$ atoms) content and $\mathrm{Na} /(\mathrm{Na}+\mathrm{K})$ ratio $(0.09$ to 0.10$)$ in muscovite coincide with calculated isopleths in the selected stability field and confirm the ratability of the model. In addition, calculated temperatures from Ti-in-biotite thermometer $\left(570-640{ }^{\circ} \mathrm{C}\right.$, Henry et al., 2005) limit the association to the high-temperature part of the field and are very close to the range obtained from $\mathrm{Zr}$-inrutile thermometer $\left(563-633^{\circ} \mathrm{C}\right.$, Zack et al., 2004). The amphibolite facies conditions $\left(550-650{ }^{\circ} \mathrm{C}\right.$ and $4.5-6.5 \mathrm{kbar}$ ) are well constrained by the thermodynamic modelling, mineral composition isopleths and conventional thermometry.

\section{Conclusions}

The thermodynamic modelling corroborates petrographic observations, mineral chemistry and conventional thermometry, and places certain P-T constraints of the studied metasedimentary sequence. The investigated phyllite of western Sakar unit (Klokotnitsa village area) reveals metamorphic peak at greenschist conditions $\left(\mathrm{T}=250-350{ }^{\circ} \mathrm{C}\right.$ and $\mathrm{P}=2-4$ kbar). The syn- to post-kinematic associa- tion in calcite-biotite schist of eastern Sakar Unit (Topolovgrad town area) indicates amphibolite facies metamorphism $\left(\mathrm{T}=550-650{ }^{\circ} \mathrm{C}\right.$ and $\mathrm{P}=4.5-6.5$ kbar). Similar P-T conditions $\left(\mathrm{T}=536-658^{\circ} \mathrm{C}\right.$ and $\mathrm{P}=3.5-8 \mathrm{kbar}$ ) have been reported for post-kinematic mineral association in metapelites from the Topolovgrad area (Tzankova, Pristavova, 2007). The well visible in the field increase of metamorphic grade in west-east direction is confirmed in this study by the mineral composition data and the thermodynamic modelling. The greenschist-amphibolite facies metamorphic event affected the Triassic sedimentary cover within the Sakar unit and is related to its Alpine evolution.

Acknowledgements: This work was supported by the Bulgarian Ministry of Education and Science under the National Research Program "Young scientists and postdoctoral students" approved by DCM \# 577 / 17.08.2018 and by National Scientific Fund, project DN 14/5 2017.

\section{References}

Chatalov, G. 1990. Geology of the Strandza Zone in Bulgaria. Geologica Balc., Series Operum Singulorum 4. Sofia, Bulg. Acad. Sci. Publishing House, 263 p. (in Bulgarian with English abstract).

Chavdarova, S., Ph. Machev. 2017. Amphibolites from Sakar Mountain - geological position and petrological features. - Proc. Nat. Confer. Bulg. Geol. Soc., Geosciences 2017, 49-50.

Connolly, J. A. D. 2009. The geodynamic equation of state: what and how. - Geochem. Geophys. Geosyst., 10, Q10014; https://doi.org/10.1029/2009GC002540.

Henry, J. D., C. V. Guidotti, J. A. Thomson. 2005. The Tisaturatiom surface for low-to-medium pressure metapelitic biotites: Implications for geothermometry and Ti-substitution mechanisms. - Am. Mineral., 90, 316-328; https://doi. org/10.2138/am.2005.1498.

Hey, M. H. 1954. A new review of chlorites. - Mineral. Mag. J. Mineral. Soc., 30, 224, 278-292; https://doi.org/10.1180/ minmag.1954.030.224.01.

Hillier, S., B. Velde. 1991. Octahedral occupancy and chemical composition of diagenetic (low-temperature) chlorites. - Clay Minerals, 26, 149-168; https://doi.org/10.1180/ claymin.1991.026.2.01.

Ivanov, Zh. 2017. Tectonics of Bulgaria. Sofia, St. Kliment Ohridski Publishing House, 331 p. (in Bulgarian with English abstract).

Tzankova, N., P. Pristavova. 2007. Metamorphic evolution of garnet-bearing schists from Sakar Mountain, Southeastern Bulgaria. - C. R. Acad. bulg. Sci., 60, 3, 271-278.

Zack, T., R. Moraes, A. Kronz. 2004. Temperature dependence of $\mathrm{Zr}$ in rutile: empirical calibration of a rutile thermometer. - Contrib. Mineral. Petrol., 148, 471-488; https://doi. org/10.1007/s00410-004-0617-8. 